\title{
GYPSUM KARST CAUSES RELOCATION OF PROPOSED CEDAR RIDGE DAM, THROCKMORTON COUNTY, TEXAS
}

\author{
Kenneth S. Johnson
}

Oklahoma Geological Survey, 1321 GreenbriarDr., Norman, OK 73072, USA, ksjohnson@ou.edu_

\section{J. Mark Wilkerson}

Fugro Consultants, Inc., 2880 Virgo Lane, Dallas, Texas 75229, USA, mwilkerson@fugro.com

\begin{abstract}
Cedar Ridge Dam and Reservoir will be built to supply water for the city of Abilene, Texas. The original damsite (CR) was to be located on Clear Fork of Brazos River in Throckmorton County, but initial coring of the damsite encountered unsuspected gypsum beds in the Permianage Jagger Bend/Valera Formation. Gypsum is a highly soluble rock that typically contains karst features, and its presence in a dam foundation or impoundment area could allow water to escape from the reservoir. A decision was made to look at potential sites farther upstream (to the southwest), where west-dipping gypsum beds would be deeper underground and karst problems would be minimized or eliminated.
\end{abstract}

The first phase of the relocation was a comprehensive field study of Clear Fork Valley, upstream of the original damsite, to identify gypsum outcrops; gypsum was exposed at only one location, just above damsite CR. The second phase of the study was examination of nearly 100 petroleum-test geophysical $\operatorname{logs}$ to identify, correlate, and map the subsurface gypsum and associated rock layers upstream of the original damsite. The gypsiferous sequence is $30-45 \mathrm{~m}$ thick, and consists of 8 gypsum beds, mostly 1-3 $\mathrm{m}$ thick, interbedded with redbrown and gray shale units 1-10 m thick. Gypsum beds comprise $25-30 \%$ of the gypsiferous sequence. Gypsum beds dip uniformly to the west at about 7 $\mathrm{m} / \mathrm{km}$ (about 0.4 degrees), and thus the uppermost gypsum is at least $23 \mathrm{~m}$ beneath the newly proposed damsite (A), about $8 \mathrm{~km}$ to the southwest.

Subsequent coring and other studies of the new damsite A confirm that gypsum beds are $23 \mathrm{~m}$ beneath the newly proposed dam. There is no evidence of solution channels or other karst features beneath this site, and thus there is little likelihood of water loss from the reservoir at the new site due to gypsum karst.

\section{Introduction}

This study examines aspects of the subsurface geology of an area along the Clear Fork of Brazos River (Clear Fork) in parts of Throckmorton, Haskell, Shackelford, and Jones Counties, Texas (Figure 1). The study area extends from the town of Lueders in the southwest to Paint Creek in the northeast. It includes the originally proposed Cedar Ridge Reservoir damsite (CR) and the newly proposed damsite (site A), located about $8 \mathrm{~km}$ farther upstream (to the southwest). The study focuses on the distribution, thickness, and structure of a series of gypsum beds present in the Permian-age Jagger Bend/Valera Formation, which dips gently to the west at a rate of about $7 \mathrm{~m} / \mathrm{km}$.

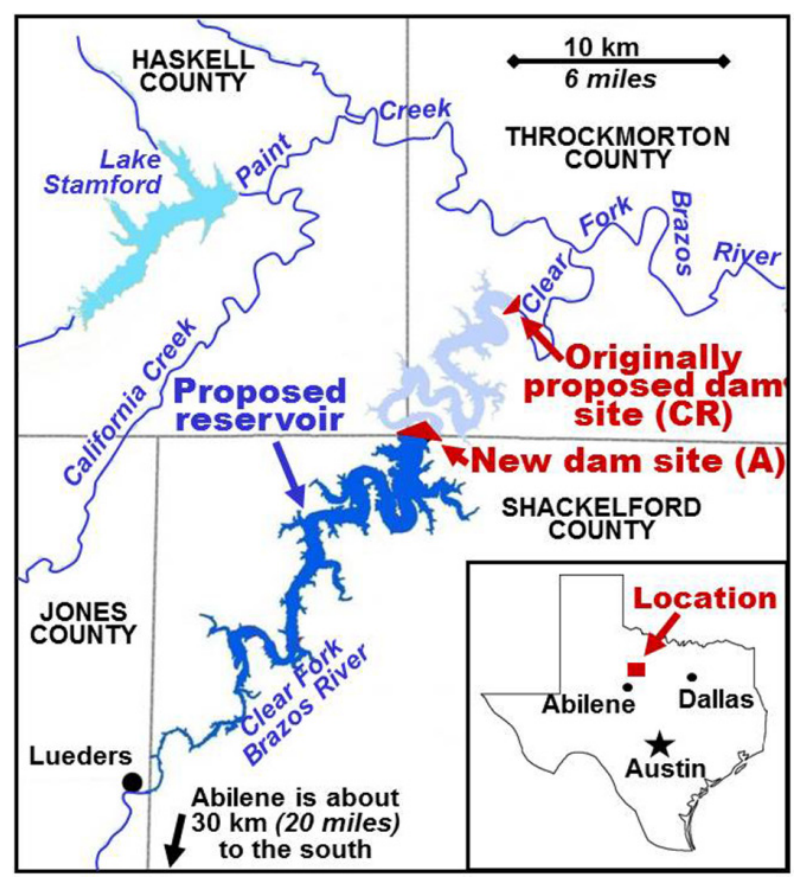

Figure 1. Location map showing originally proposed Cedar Ridge Reservoir damsite (CR), and site of the newly proposed dam (A) and reservoir. 
The current study was prompted by the unexpected discovery of significant beds of karstic gypsum at the originally proposed damsite during a preliminary investigation in the summer of 2008. Because gypsum was not known to crop out in the area (it is eroded, dissolved, or soil-covered), previous geologic maps and studies of the area made no mention of gypsum occurrences in the Jagger Bend/Valera Formation. So, not only was it a surprise to discover karstic gypsum in preliminary cores at the original damsite, but also a blowout of natural gas was encountered at a depth of 20 $\mathrm{m}$ beneath the proposed dam alignment at CR.

Gypsum is a highly soluble rock. Generally, it is susceptible to partial or total dissolution by ground water, and may develop karst features such as caves, sinkholes, and underground water courses (Johnson 2003a, 2008a). Gypsum beds underlie all parts of the study area: they crop out at one small site about $1 \mathrm{~km}$ upstream of CR, and should also be present along the river for several $\mathrm{km}$ farther upstream in the Clear Fork Valley (however, they do not crop out). Due to the potential for gypsum karst along this portion of the river, the distribution and depth of the various gypsum beds are important factors to consider when choosing the final damsite along Clear Fork.

Gypsum karst is an important consideration in dam location and construction because it has had an adverse impact on holding water behind a dam at several sites in the United States. Dams built upon gypsum karst generally have difficulty in retaining water, and can even result in collapse and failure of the dam (Johnson, 2008a, $2008 b$ ). If gypsum karst is located within the proposed impoundment area of a reservoir, water can penetrate the karst features and may escape from the reservoir. Several articles have been published on properties of dam foundations built upon gypsum deposits (James and Lupton, 1978; Chen and Wu, 1983; Milanović, 2000).

Several examples of gypsum-karst problems and dams in the United States are: Quail Creek Dike (Utah), Upper Mangum Dam (Oklahoma), Anchor Dam (Wyoming), and Horsetooth and Carter Lake Dams (Colorado) (Johnson, 2008b). Quail Creek Dike failed in 1989 due, in part, to flow of water through an undetected gypsum-karst unit beneath an earth-fill embankment (James and others, 1989; O'Neill and Gourley, 1991; Payton and Hansen, 2003). The long-studied Upper Mangum Dam was abandoned before construction, because of extensive gypsum karst in the abutments and impoundment area (Johnson, 2003b). Anchor Dam, built in 1960, has significant drainage of water from the reservoir because of earth fissures, sinkholes, and gypsum karst that underlie the impoundment area (Jarvis, 2003). Horsetooth and Carter Lake Reservoirs, built upon gypsum-bearing strata in the 1940s, experienced development of sinkholes and seepage-loss of water in the 1980s and 1990s (Pearson, 2002).

\section{Methods of Study}

Determining the subsurface distribution, thickness, and structure of gypsum beds in the study area required examining the electric logs (also known as "geophysical logs") of nearly 100 oil and gas tests drilled within a 13 x $30-\mathrm{km}$ area that extends about $6 \mathrm{~km}$ on each side of Clear Fork. Recognition of gypsum beds and associated rock types on electric logs is well established (Alger and Crain, 1966), and the senior author has conducted many studies using various types of well logs to identify, correlate, and map gypsum beds in the subsurfacesome of these studies are available in public documents (Johnson, 1967, 1981, 1985, 1989a, 1989b, 1993), and many others are contained within consulting reports.

On each well log examined in the study area, individual gypsum beds (and interbedded shale units) that are at least $0.5 \mathrm{~m}$ thick can be identified readily (Figures 2, 3, 4). Recognition and identification of gypsum beds on the electric logs is confirmed by comparison and correlation with continuous cores that were drilled near several of the oil wells. Figure 2 shows Core B-3, drilled on May 21, 2008, at the original Cedar Ridge damsite. The core contains gypsum beds, $0.3-2 \mathrm{~m}$ thick, that are readily correlated with gypsum beds interpreted to be present on electric logs for two wells (\#69 and \#66) drilled 100 $\mathrm{m}$ and $3 \mathrm{~km}$, respectively, away from the core. There is almost a bed-for-bed correlation of the gypsums from Core B-3 with those in Well 69, and also a good correlation with those in Well 66, located $3 \mathrm{~km}$ away. Well 66 contains several thin gypsum beds at the top of the sequence that are missing in Core B-3.

Farther to the southwest, in the vicinity of newly proposed damsite A, gypsum beds in Core B-5 (drilled March 31, 2009) are readily correlated with those in the electric log of Well 2-5, located about $900 \mathrm{~m}$ away (Fig. 3). The gypsum beds, 0.3-3 m thick, are herein informally named A through $\mathrm{H}$ (in ascending order): these names 


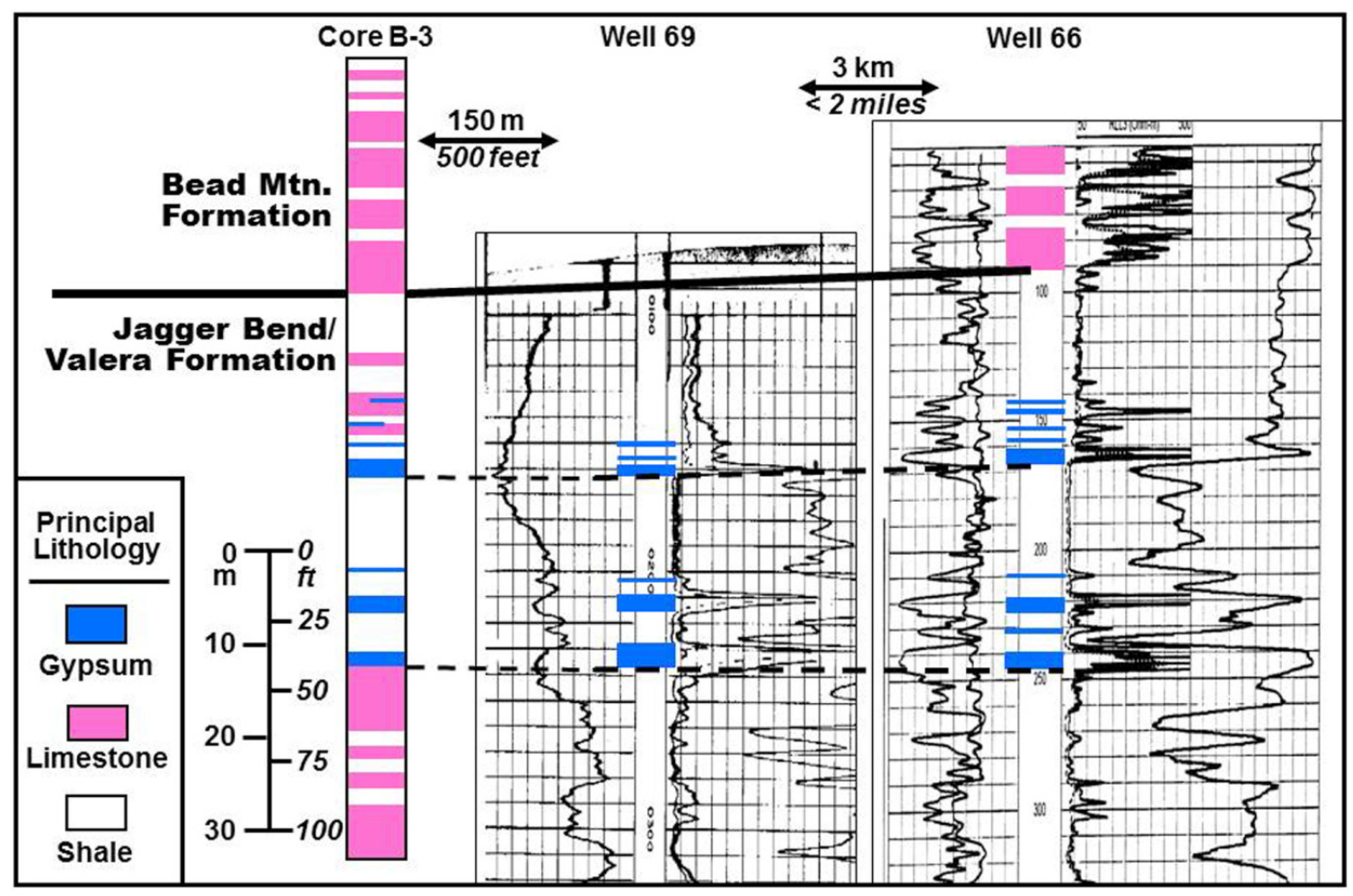

Figure 2. Gypsum beds in Core B-3, drilled at the original Cedar Ridge damsite (CR), are correlated with electric logs of nearby oil wells.

are shown on the left side of Core B-5 (Figure 3). Also showing up very clearly is another rock unit that is herein referred to informally as the "Upper Shale": this shale is 6-10 m thick, and immediately overlies gypsum H. In Cores B-3 and B-5, the shales interbedded with gypsum are generally $1-10 \mathrm{~m}$ thick.

\section{Results of Study}

With recognition of gypsum and shale beds on these electric logs (Figures 2, 3), confirmed through examination of nearby cores, it is then possible to confidently identify and correlate individual gypsum and shale units of the Jagger Bend/Valera Formation on other electric logs throughout the study area (Figure 4). Figure 4 is a structural cross section showing that the gypsum beds dip to the west, and therefore are deeper below the land surface and below Clear Fork to the west. It also shows that some of the gypsum beds present in the west are thinner to the east, and some of them disappear and even grade laterally into shale to the east.

The entire gypsum sequence is about $45 \mathrm{~m}$ thick near proposed damsite A, and is about $30 \mathrm{~m}$ thick in the vicinity of the original damsite CR. Gypsum beds comprise about $30 \%$ of the total thickness of

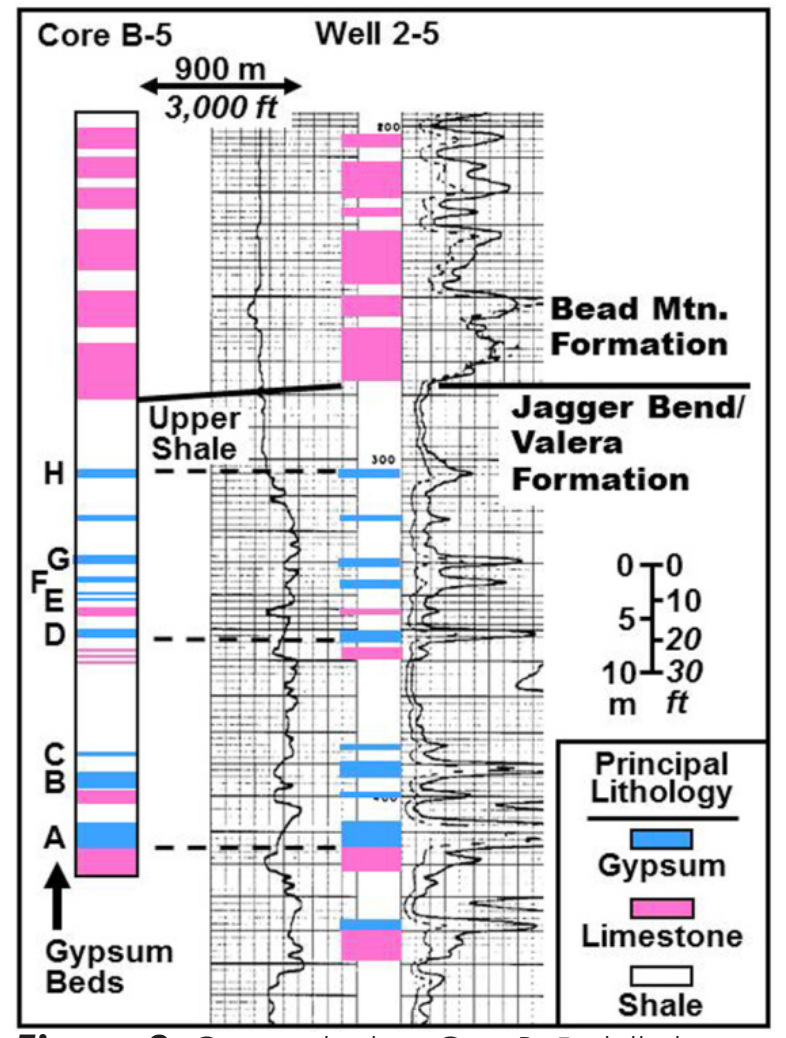

Figure 3. Gypsum beds in Core B-5, drilled near newly proposed damsite $A$, are correlated with electric log of a nearby oil well. 


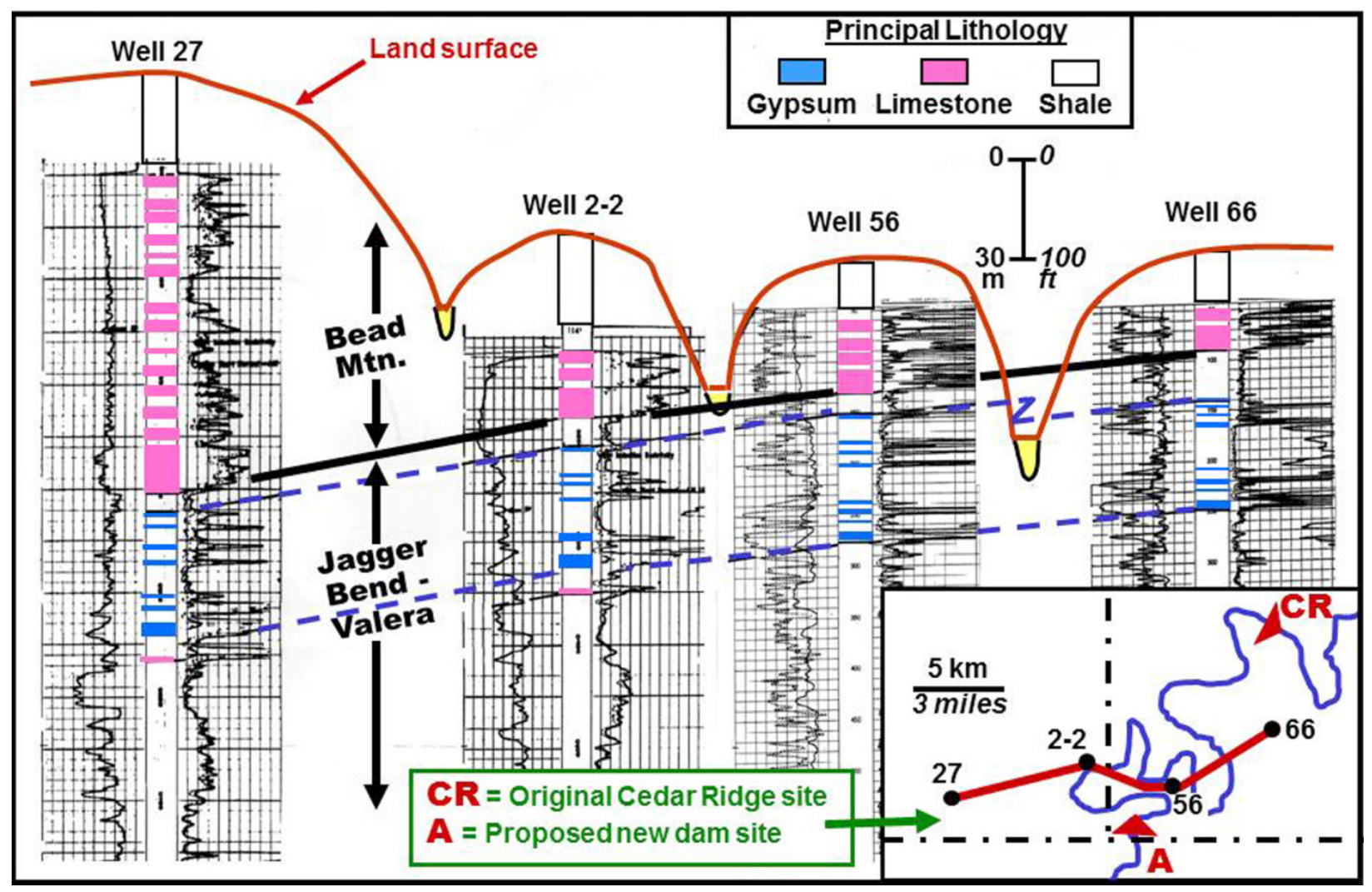

Figure 4. Structural cross section showing gypsum beds dipping down to the west. Gypsum beds thin and grade laterally into shale to the east.

the gypsum sequence near damsite $\mathrm{A}$, and about $25 \%$ of the total thickness near CR.

Upon establishing the recognition of gypsum and shale units on electric logs, all 100 of the well $\operatorname{logs}$ within a larger study area were examined and the gypsum and shale units were identified and correlated. The depth to the top of the uppermost gypsum in the sequence (gypsum $\mathrm{H}$, in most wells), was identified and plotted on a map (Figure 5). In some areas, mainly in the western part of the study area, additional gypsum beds are present above gypsum $\mathrm{H}$ and also below gypsum $\mathrm{A}$. These additional beds are considered part of the Jagger Bend/Valera gypsum sequence in those areas. Similarly, towards the east, the upper and lower gypsum beds disappear and grade laterally into shale, and the Jagger Bend/ Valera gypsum sequence becomes thinner.

Figure 5 is a structure-contour map on gypsum beds at the top of the gypsum sequence in the Jagger Bend/ Valera Formation. It shows that the gypsum units dip fairly uniformly towards the west, at about $7 \mathrm{~m} / \mathrm{km}$.

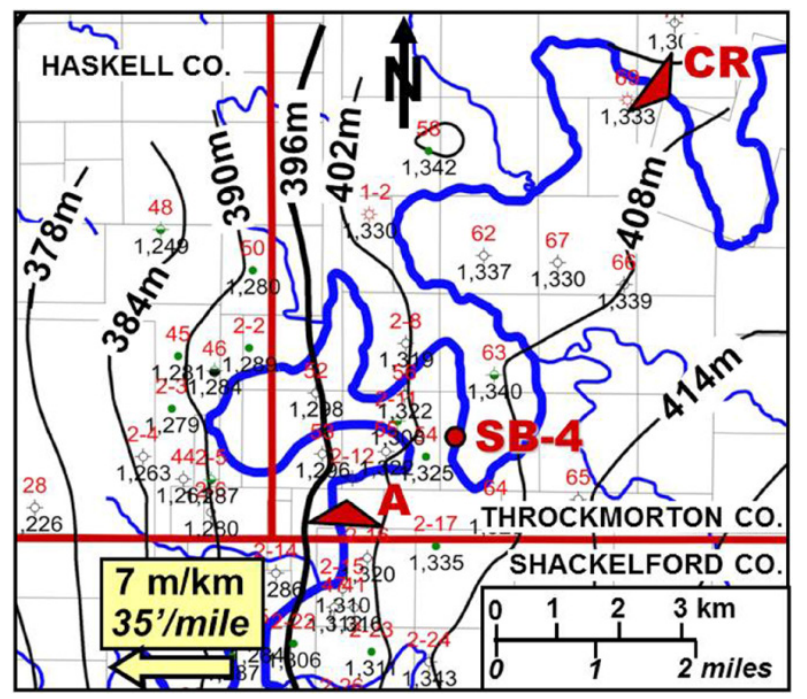

Figure 5. Structure-contour map on top of youngest gypsum bed in Jagger Bend/Valera Formation. Elevations at each well are in feet, but contour interval is $6 \mathrm{~m}$ ( \pm 20 feet).

Local irregularities do exist, where the dip is slightly higher or lower, and the direction of dip varies slightly. 
For example, the dip is about $6 \mathrm{~m} / \mathrm{km}$ in the vicinity of proposed damsite A, near the common corner of Throckmorton, Haskell, and Shackelford Counties.

Figure 5 is very significant because it shows the elevation (above sea level) of the top of the highest gypsum bed throughout the area. By comparing this map (the elevation of the highest gypsum) with topographic maps, it is possible to determine how deep the gypsum is below the land surface, and also whether gypsum beds should be exposed in the valley walls of Clear Fork. The uppermost gypsum beds are exposed, or should be exposed, in the valley of Clear Fork at and near the originally proposed Cedar Ridge Reservoir damsite (CR). Gypsum does crop out at one location near $\mathrm{CR}$, but at other places where it should crop out the gypsum is either eroded, dissolved, or is covered by alluvium, colluvium, or soil.

If a dam is constructed upon gypsum, or if lake water is impounded too closely above gypsum in Clear Fork Valley, it could be detrimental to dam integrity. Potential karst development in the gypsum could provide pathways for impounded water to escape from the reservoir and be discharged downstream of the dam. Also, if such a pathway is established, the gypsum would undoubtedly be further dissolved, and the pathway would be enlarged. Therefore, it is important to know where gypsum does, or should, crop out in Clear Fork Valley.
The elevation of the top of the gypsum sequence is about $17 \mathrm{~m}$ above stream level of Clear Fork at the original Cedar Ridge damsite, and thus the upper part of the gypsum sequence is, or should be, exposed in the valley walls (Figure 6). The top of the gypsum is then at successively lower heights above stream level in the valley upstream from CR because of: a) westward dip of the gypsum sequence (Figures 4, 5, 6); and b) the rise of stream-level elevation upstream from CR (Figure 6). The uppermost gypsum dips beneath stream level in the vicinity of borehole SB-4. Therefore, gypsum is present, or should be present (based on electric-log interpretation), in all parts of Clear Fork Valley from CR up to the vicinity of borehole SB-4 (Figures 5, 6).

The top-most gypsum (gypsum $\mathrm{H}$ ) is about $23 \mathrm{~m}$ below stream level at proposed dam A. Here the gypsum beds are believed to be deep enough below the proposed reservoir to not pose a "gypsum-karst" problem. In addition, the presence of the 6- to 10-m-thick "Upper Shale" adds a low-permeability barrier between the gypsum beds (below) and the impounded reservoir water (above).

Another result of this subsurface study is recognition that a large number of oil and gas wells have been drilled along and near Clear Fork in the study area. These wells are beneficial for the current study, because they provide many electric logs that can be used to evaluate

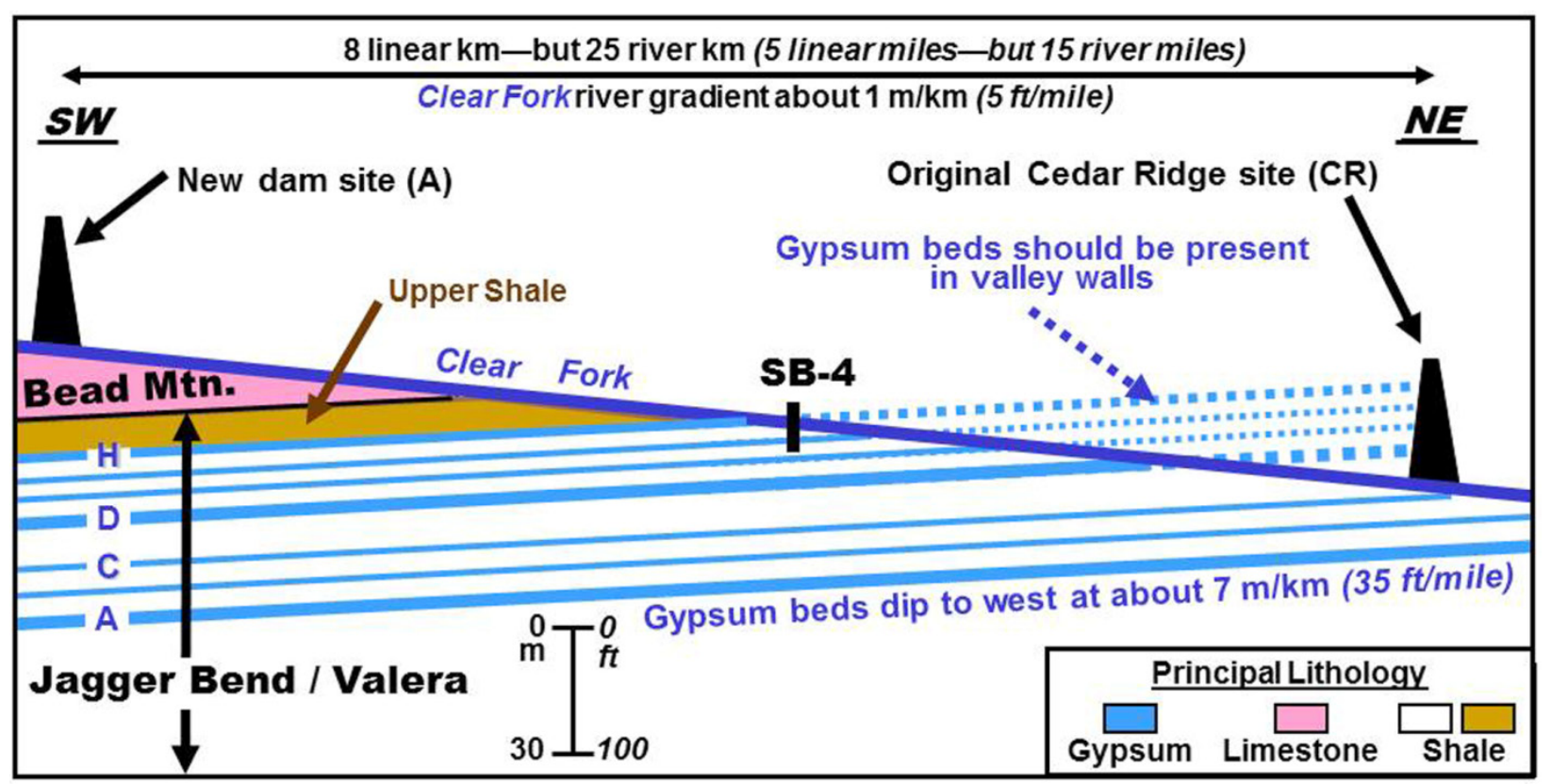

Figure 6. Schematic cross section showing west dip of gypsum beds beneath Clear Fork of Brazos River and damsites $C R$ and $A$. Top of gypsum sequence is above stream level at $C R$, and is about $23 \mathrm{~m}$ below stream level at damsite $A$. 
the thickness, depth, and distribution of gypsum beds. However, this also means that there are a large number of wells in the impoundment area of the proposed reservoir that could impact the reservoir and its water quality. These boreholes are potential pathways for oil, gas, or associated salt-water brines to seep to the surface and mix with reservoir water. They also are potential pathways for reservoir water to flow down into the gypsum beds. Producing oil and gas wells in or adjacent to the impoundment must be properly plugged and sealed; and even dry or abandoned wells within the impoundment area must be found, to ensure that they have been properly plugged and sealed.

\section{Summary}

Gypsum is a highly soluble rock that typically contains cavities, sinkholes, and caves ("karst" features), and its presence in a dam foundation or in an impoundment area could allow water to escape from the reservoir. The presence of gypsum at the original Cedar Ridge damsite (CR) on Clear Fork of Brazos River was confirmed in core holes, and a decision was made to look at potential sites farther upstream where any gypsum-karst problem would be minimized or eliminated.

The current study focused on examination of nearly 100 oil- and gas-well electric logs to identify, correlate, and map the gypsum and associated rock layers of the Jagger Bend/Valera Formation within a 13 x 30-km area encompassing Clear Fork. Gypsum beds can be identified readily on the logs, and this is affirmed by comparing several cores (B-3 and B-5) with nearby electric logs (Figures 2, 3). Gypsum beds dip fairly uniformly to the west at about $7 \mathrm{~m} / \mathrm{km}$, and at $6 \mathrm{~m} /$ $\mathrm{km}$ in the vicinity of prospective damsite A (Figures $4,5)$. Gypsum beds in the study area thin to the east; they grade laterally into shale and pinch out in that direction.

Gypsum beds crop out, or should be exposed, in the Clear Fork Valley upstream from the original Cedar Ridge damsite, all the way to the vicinity of borehole SB-4 (Figures 5, 6). The presence of gypsum beds in this portion of the valley means that there may be karst pathways whereby impounded water could escape a reservoir built downstream of SB-4. Therefore, the best location for a dam on Clear Fork would be at a site located some distance upstream from $\mathrm{SB}-4$, at a site where a sufficient thickness of the "Upper Shale" and other strata are present to separate reservoir water from the gypsum sequence.

At the newly proposed damsite (A), the Clear Fork streambed is $23 \mathrm{~m}$ above the shallowest gypsum bed, and the "Upper Shale," a low-permeability barrier just above the gypsum sequence, is $6-10 \mathrm{~m}$ thick. The latest core drilling at this site does not indicate the presence of any karst features in any of the gypsum beds. Therefore, this site appears to be favorable and warrants further investigation.

\section{References}

Alger RP, Crain ER. 1966. Defining evaporite deposits with electrical well logs. In: Rau JL, editor. Second symposium on salt. The Northern Ohio Geological Society, Inc., vol. 2, p. 116-130.

Chen F, Wu M. 1983 Investigation of the engineering properties of a dam foundation containing gypsum seams. Rock Mechanics and Rock Engineering 16: 275-280.

James AN, Lupton ARR. 1978 Gypsum and anhydrite in foundations of hydraulic structures. The Institution of Civil Engineers (London), Géotechnique 28 (3): 249-272.

James RL, Catanach RB, O’Neill AL, Von Thun JL. 1989. Investigation of the cause of Quail Creek Dike failure. Unpublished report of the Independent Review Team to Norman H. Bangerter, Governor of Utah. 155 p.

Jarvis T. 2003. The Money Pit: karst failure of Anchor Dam. In: Johnson KS, Neal JT, editors. Evaporite karst and engineering/environmental problems in the United States. Oklahoma Geological Survey Circular 109. p. 271-278.

Johnson KS. 1967. Stratigraphy of the Permian Blaine Formation and associated strata in southwestern Oklahoma [PhD dissertation]. Champaign (IL): University of Illinois. 247 p.

Johnson KS. 1981. Dissolution of salt on the east flank of the Permian Basin in the southwestern U.S.A. Journal of Hydrology 54: 75-93.

Johnson KS. 1985. Structure contour map and stratigraphic/hydrologic data on the Blaine aquifer in the Hollis Basin of southwestern Oklahoma. Oklahoma Geological Survey Open-File Report. Scale 1:125,000.

Johnson KS. 1989a. Development of the Wink Sink in West Texas, U.S.A., due to salt dissolution and collapse. Environmental Geology and Water Sciences 14 (2): 81-92. 
Johnson KS. 1989b. Salt dissolution, interstratal karst, and ground subsidence in the northern part of the Texas Panhandle. In: Beck BF, editor. Engineering and environmental impacts of sinkholes and karst. Proceedings of the 3rd Multidisciplinary Conference on Sinkholes and the Engineering and Environmental Impacts of Karst, St. Petersburg, Florida: A. A. Balkema Publishers, Brookfield, VT. p. 115-121.

Johnson KS. 1993. Dissolution of Permian Salado salt during Salado time in the Wink area, Winkler County, Texas. In: Love DW, and others, editors. Carlsbad region, New Mexico and west Texas. New Mexico Geological Society Guidebook, 44th Annual Field Conference. p. 211-218.

Johnson KS. 2003a. Evaporite-karst problems in the United States, In: Johnson KS, Neal JT, editors. Evaporite karst and engineering/environmental problems in the United States. Oklahoma Geological Survey Circular 109. p. 1-20.

Johnson KS. 2003b. Gypsum karst and abandonment of the Upper Mangum Damsite in southwestern Oklahoma, In: Johnson KS, Neal JT, editors. Evaporite karst and engineering/environmental problems in the United States. Oklahoma Geological Survey Circular 109. p. 85-94.

Johnson KS. 2008a, Evaporite-karst problems and studies in the USA. Environmental Geology 53: 937-943.

Johnson KS. 2008b. Gypsum-karst problems in constructing dams in the USA: Environmental Geology 53: 945-950.

Milanović PT. 2000. Geologic engineering in karstdams, reservoirs, grouting, groundwater protection, water tapping, tunneling. Belgrade, Yugoslavia: Zebra Publishing Ltd. 347 p.

O'Neill AL, Gourley C. 1991. Geologic perspectives and cause of the Quail Creek dike failure. Association of Engineering Geologists Bulletin 27 (2): 127-145.

Payton CC, Hansen MN. 2003. Gypsum karst in southwestern Utah: Failure and reconstruction of Quail Creek Dike, In: Johnson KS, Neal JT, editors. Evaporite karst and engineering/environmental problems in the United States. Oklahoma Geological Survey Circular 109. p. 293-303.

Pearson RM. 2002 Gypsum karst of the Lykins Formation and effects for Colorado Front Range water projects: Horsetooth and Carter Lake Reservoirs. Geological Society of America Abstracts with Programs 34 (6): 216. 
